\title{
THE MISSISSIPPI RIVER IMPROVEMENTS.
}

\author{
Report of Captain Jas. B. Eans, to Mr. Jchius S. Walsh, President of the South \\ Pass Jetty Company.
}

SIR :-I have the honor to submit the following report upon the improvement of the South Pass of the Mississippi river:

Head of Pass. - The depth on the shoal in the river obstructing the entrance to South Pass was $14 \mathrm{ft}$., or $15 \mathrm{ft}$. at low water, when the jetties at the mouth were begun. Until late in October, 1876, this shoal remained almost intact, while the channel between the jetties, 12 miles distant, had rapidly improved; and although $20 \mathrm{ft}$. of water could be carried out of the pass to sea, this was not a vailable for commerce, because of the shoal obstructing the entrance at its head.

To create a channel through this shoal, an additional system of works was designed and constructed at the head of the pass, including two submerged mattress sills, $2 \mathrm{ft}$. thick, $70 \mathrm{ft}$. wide, and each over $3000 \mathrm{ft}$. long. These were sunk on the hottom of the river, across the entrance to South-west Pass, and Pass à l'Outre. The South Pass discharges only about one-tenth of the entire volume flowing out of the three passes, and these sills were designed to prevent any enlargement of the two great passes, and thus hasten the scouring action on the bottom of the new channel into South Pass. They are laid in deep water, and $30 \mathrm{ft}$. of depth can be carried into both passes over them. They are well ballasted with stone, and soundings show that the bottom of the river is now level with the tops of the sills. They will, therefore, be ikely to remain permanently in their present position. These sills diminish the entrance into these two great passes about 7000 square feet each.

The works at the pass actually embrace and control the entire discharge of the Mississippi river, which is at this point one mile and three-quarters wide. They, therefore, surpass in magnitude any similar works in the world. By them the wide funnel-shaped entrance to South Pass has been permanently converted into a narrower and

Whole No, Voi.. CIV.-(Third Skries, Vol, lxxiv.) 
parallel one of $850 \mathrm{ft}$. in width. With the exception of the east dyke, they were commenced after the flood of 1876 had begun to subside, and in October had so far progressed as to control the flow into the pass. The use of dredge boats was then resorted to on the centre line between the parallel piers, within which the new channel has been formed, to hasten its development. These succeeded in cutting a narrow channel, of about $20 \mathrm{ft}$. in depth, through the shoal; but owing to the exceptionally low stage of the river at this time, the current was so feeble, that but little impression was made by the river through this dredged cut, and on the 1st of February it was not sufficiently widened to be available for vessels drawing over $15 \mathrm{ft}$., or $16 \mathrm{ft}$.

As the present depth of the bar at the mouth is no greater than it was when the works at the head were completed, nor indeed as great, the cause which interrupted the deepening that had previously proceeded with such remarkable regularity between the jetties, will be fully understood when the effect of the works at the head of the pass is considered.

Before the works there were built, the width, on the crest of the shoal, of the volume of water flowing into South Pass, measured transversely to the current, was $2400 \mathrm{ft}$. A concentration of this volume between parallel piers only $850 \mathrm{ft}$. apart, was relied on to secure the requisite depth of channel through the shoal, but this concentration (as will be seen by a chart of the works) could only be obtained by the erection of dams and piers, which greatly diminished the flow into the pass, and thus, for the time being, completely suspended the erosive action of the current between the jetties 12 miles below them.

During November, December, and January last, owing to the extremely low stage of the river, we were not justified in expecting scour through the works at the head of the pass, but were prepared to find deposits in the pass, and also between the jetties. To rob the pass, even temporarily, of so large a portion of its water, as was for the time barred out by our works at the head, necessarily reduced its current and caused considerable deposits to be thrown down during the time so much water was excluded.

Under these circumstances the rise in the river was looked for with considerable anxiety. It occurred about the 1st of February, and, as was expected, soon caused a rapid enlargement of the channel 
through the shoal that had for so many years obstructed the entrance into the pass. Seventy thousand $(70,000)$ cubic yards of sand were excavated by the current during the first seven days of February. Since that date, as the charts sent to you from time to time, show, the enlargement of the channel through the shoal has been going on with great rapidity, and upwards of 450,000 cubic yards have been excavated from it up to the present time.

The following table gives in detail the extent of its enlargement to May 23, 1877 :

Date of Survey.

$\begin{array}{cc}\text { Least Width } & \text { Least Width } \\ \text { of } 20 \mathrm{ft} . & \text { of } 30 \mathrm{ft} . \\ \text { channel. } & \text { channel. } \\ \mathrm{ft} . & \mathrm{ft.}\end{array}$

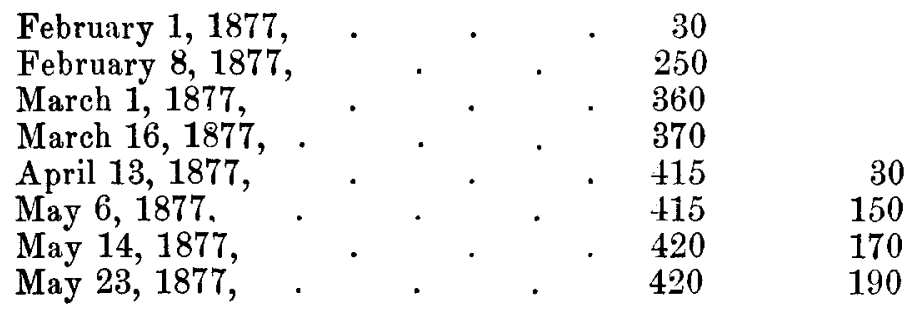

No detailed survey has been made of the head of the pass recently, but occasional soundings show continued enlargement. The works there will need no further expenditure this year, and the entire force employed in their construction has been discharged.

Although the February rise soon declined, and the next one did not come till the middle of March, the relief which the sudden enlargement of the entrance gave to the whole pass below, was readily observed in the channel between the jetties. The river water was heavily charged with sediment, but no new deposits were found in the jetty channel. During the month of February little or no change between the jetties occurred; the least depth on the bar was 20.04 $\mathrm{ft}$., and the least width of the $20 \mathrm{ft}$. channel was $130 \mathrm{ft}$.

The Jetty Channel.-By the end of February the restoration of the full flow into the pass was felt in the jetty channel. Early in March a scour commenced in the upper portion of the jetty channel, and the enlargement of the channel very soon assumed remarkable dimensions. This enlargement has gradually extended down, and is now at a point $9000 \mathrm{ft}$. below the upper end of the east jetty. Its greatest depth on the $22 \mathrm{~d}$ of June was $89 \mathrm{ft}$. at a point about one mile below the upper end of the jetty, and where the United States 
Coast Survey map of 1875 shows a depth at that time of only $13 \mathrm{ft}$. The width of the $22 \mathrm{ft}$. channel through this $9000 \mathrm{ft}$. varies from $300 \mathrm{ft}$. to $500 \mathrm{ft}$. The $30 \mathrm{ft}$. channel is at one place $500 \mathrm{ft}$. wide. No scour occurs near either jetty, the deepening being confined to the central part of the channel.

To this extraordinary scour is to be attributed a slight deposit at the lower end of the jetties, which was observed to take place simultaneously with the scour in the upper portion of the channel. Careful estimates from a survey made in May, show, that since the end of March, 544,103 cubic yards had been scoured from between the jetties above station 80 , while only 77,315 cubic yards of this amount have been deposited below that point near the sea ends of the jetties. The balance-466,788 cubic yards, or 86 per cent. of the whole scour-was completely transported into the gulf, and has been carried by the current far beyond the reach of our surveys.

Expressed in a more graphic form, the amount moved in 58 days from between the jetties, in a distance of $5000 \mathrm{ft}$. is equal to a mass of earth $900 \mathrm{ft}$. in length, $544 \mathrm{ft}$. in breadth, and $30 \mathrm{ft}$. high. This is equal to 9381 cubic yards removed each day.

When we consider that the volume of water, charged with this enormous quantity of sedimentary matter (in addition to what it had brought down from the river to the jetties), had, just before entering the gulf, to travel up a slope against the tides and winds, the fact, that only 14 per cent. of over half a million cubic yards of sand was dropped before it reached the end of the jetties, is one of the most encouraging features yet developed in connection with the jetty improvement.

On the $25 \mathrm{th}$ of April, the $22 \mathrm{ft}$. channel, $200 \mathrm{ft}$. wide, only extended uninterruptedly down between the jetties to station 68 ; or 6800 ft. Forty-eight days afterwards, June 12, it had been enlarged to $300 \mathrm{ft}$. in width, and then reached to station 90 , or $2200 \mathrm{ft}$. further down than on April 25, thus averaging nearly $46 \mathrm{ft}$. per day in its progress to the sea. As the next payment from the United States will be due when a channel $22 \mathrm{ft}$. deep, by $200 \mathrm{ft}$. in width, is obtained through the jetties, the rate of enlargement since April 25 , furnishes a basis on which to found a reasonable expectation as to the time when the next payment will be earned. The distance yet to be enlarged to 22 by $206 \mathrm{ft}$, , and thus give a channel of that size through to deep water, was, on the 12 th of June, $3000 \mathrm{ft}$. At 
the rate of $46 \mathrm{ft}$. per day it should be through by the 16th of August. On the 20 th of this month the $22 \mathrm{ft}$. channel had reached a point only $450 \mathrm{ft}$. from the deep water of the sea, but below station 90 it had only a width of $140 \mathrm{ft}$.

The Gulf in Front of South Pass.-A careful investigation was made last month of the condition of the gulf bottom, directly in front of the jetties, in order to ascertain what effect an almost uninterrupted scour of nearly two years' duration would produce. An area of 51.7 acres extending $2730 \mathrm{ft}$. seaward from the old crest of the bar, was covered with a large number of soundings accurately located by reference to the triangulation stations of the United States Coast Survey. The results of this examination were then compared with the chart of the coast survey of May, 1875, when the following results were ascertained.

The volume of water within this 51.7 acres, directly beyond the old crest of the bar, was:

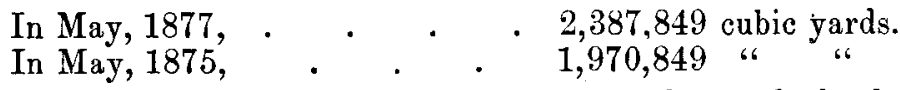
showing a gain of water within this area in front of the bar of 417,000 cubic yards, which is equivalent to an average increase of depth of very nearly 5 feet over the entire area investigated. In May, 1876, a similar examination had been made of the same area, showing an average gain in depth from May, 1875, to May, 1876, of $2.47 \mathrm{ft}$. From May, 1876, to May, 1877, the average gain in depth was $2.52 \mathrm{ft}$. These facts seem to clearly prove, that as the compact discharge from the jetties increases in depth by the erosion of the bar, the moving prism of river water compels the sea current, which is almost constantly passing under it on the outer slope of the bar in a direction transverse to the river's discharge, to scour out more room for itself under the outflowing volume from the jetties.

The apprehended re-formation of the bar in front of the jetties is shown by these facts to be unfounded; and it, together with the fear that the pass itself would deteriorate and fill up under the effect of the jetties, may be laid aside forever.

Condition of the Works. - The jetties are in excellent condition. The works have been constructed under the immediate supervision of Colonel James Andrews, who had, until the 1st of June, an unusually large force employed. The portions which had sunk by the compression of the mattresses owing to the deposition of sand and 
other sedimentary matters in the mattress work, have been built up above high tide, entirely out to the sea ends of both jetties. The recommendations of the commission of the United States engineers, who, under orders of the Secretary of War, inspected the South Pass improvements last November, have been carefully observed, and the jetties have been well ballasted with stone, as suggested by them. The grant is being executed in perfect good faith, and the structures, as far as then completed, were acknowledged by this commission to be of the permanent and substantial character required by law.

The works have been thoroughly tested by some very severe storms since last December, but with the exception of the destruction of a few mattresses at the sea ends of the jetties, which had not been previously ballasted with stone, the damage done to them was very slight.

Some anxiety has been expressed as to the destructive effects of the teredo upon the willows and piles used in the construction of the works. Fears upon this point are groundless, for the reason that the teredo does not attack wood covered with sediment. The piles used in the work constitute no part of the permanent jetties. The core or interior of the jetties is formed of willow mattresses. These become completely filled with sediment so soon as the current ceases to pass through them. Their exposed surfaces are covered with stone ballast, which in like manner becomes filled with sediment, and this completely protects the willow work from the attack of the worm.

The various surveys referred to have been made under the supervision of Mr. E. L. Corthell, resident engineer, and Mr. Max E. Schmidt, chief assistant, aided by Mr. Webb and Mr. Morton, assistant engineers; to all of whom I am much indebted for prompt and intelligent co-operation.

Official Orders.-I take great pleasure in stating that the honorable Secretary of War has issued such orders as will permit the prompt delivery to me of the results of examinations and surveys made from time to time by Captain M. R. Brown, United States Engineer Corps, United States inspecting officer of the jetties. He has also directed Captain Brown to establish such regulations for the navigation of the pass, as will protect the tugs, barges, etc., of the jetty contractors from injury by the too rapid movement of the steamers using the pass. 
Results.-Our works were begun two years ago in an unused outlet of the Mississippi river, and have necessarily disturbed the regimen governing the outflow to the sea of an enormous volume of water; but the theories upon which they were based have been fully vindicated by the results produced; and it is now manifest that entire and complete success will reward our labors. Among the prominent results developed by our operations, are the following:

1. The concentration of the water flowing across the sand bar at the mouth of the pass by the jetties, created a channel over $200 \mathrm{ft}$. wide, in no place less than $20 \mathrm{ft}$. deep, where only about $8 \mathrm{ft}$. previously existed.

2. The concentration of the water flowing over the shoal in the river, at the head of the pass, created a channel over $400 \mathrm{ft}$. wide, in no part of it less than $20 \mathrm{ft}$. deep, with the central part $30 \mathrm{ft}$. deep, where but $14 \mathrm{ft}$. to $15 \mathrm{ft}$. previously existed.

3. During the time in which a portion of the flow into the pass was interrupted by the works at its head, and the current consequently slackened, a temporary deposit took place in the pass and between the jetties.

4. The gradual restoration of the normal flow into the pass through the new channel at its head has already begun to enlarge the pass again, and has, since this restored flow commenced, removed from between the jetties within the past three months over half a million cubic yards of deposit, and given through more than half the length of the jetties a much larger and deeper channel than ever previously existed, the size of which is already throughout more than $2000 \mathrm{ft}$. $28 \mathrm{ft}$. by $300 \mathrm{ft}$., or that required to entitle us to the fifth payment from the United States, while many hundred feet of it exceed 30 $\mathrm{ft}$. by $350 \mathrm{ft}$.

5. The gulf current athwart the jettied mouth of the pass effectually prevents the re-formation of the bar in advance of the jetties by deepening the outer slope of the bar, and sweeps away any such portion of the discharged sediment as the river current fails to carry to unknown distances seaward.

6. The Mississippi river at the head of the passes, where it has a width of over $9000 \mathrm{ft}$., is brought under complete control by our works, which are so designed as to enable us to increase or limit the discharge into our pass, if hereafter necessary; with but little additional outlay. 
7. Finally, I may add with absolute certainty, that this entire system of works is now so far completed, that no financial difficulties can intervene to arrest the processes of nature, which are constantly operating to enlarge and perfect the desired channel through them.

$$
\text { JAs. B. EADs, Chief Engineer. }
$$

\section{Report on the Depth of Water, at South Pass.-Capt.} M. R. Brown, of the United States Engineers, stationed at the South Pass of the Mississippi, in his recent report on the progress of the work on Capt. Eads' Jetties, says that the expenditures upon this work during the last four or five months, have been much greater than during any other equal period since it was begun. The result is that there is now an uninterrupted channel entirely through the pass to the sea, $20 \frac{6}{10}$ feet deep on an average at flood tide; that with the exception of one small mud lump, the twenty-two feet channel is 200 feet wide all the way through to within about 1200 feet of the sea. From this point, the twenty-two feet channel is narrower to within 145 feet of the sea. The lump mentioned, and the last 145 feet, are the only obstructions to prevent a vessel drawing twenty-two feet of water from passing through from the river to the gulf.

The River and Harbor bill of 1876 , contains a proviso, that when there shall be an open channel with eighteen feet of water at mean tide, from the sea through the jetties to the port of New Orleans, no part of the $\$ 100,000$ appropriated for dredging at the mouth of the Mississippi River shall be any longer available, and it is believed that the Secretary of War will soon order the work at the Southwest Pass to be suspended.

Relations of Light and Electrical Conductivity. - Dr. R. Börnstein obtains the following results: "The property of experiencing a diminished electrical resistance under the influence of Iuminous rays, is not confined to the metalloids selenium and tellurium, but belongs also to platinum, gold and silver, and in all probability to metals in general. The electrical current diminishes both the conductivity and the sensitiveness to light, of its conductor, and both of those, after cessation of the current, gradually acquire their former values.-L., E. and D. Phil. Mag., June, 1877., Supp't. 